\title{
Deceptive Presentation of Infectious Esophagitis
}

\author{
Rui Mendo ${ }^{a}$ Catarina Félix ${ }^{a}$ Pedro C. Figueiredo ${ }^{a, b}$ \\ ${ }^{a}$ Department of Gastroenterology, Centro Hospitalar de Lisboa Ocidental, Hospital de Egas Moniz, Lisbon, Portugal; \\ ${ }^{b}$ Department of Gastroenterology, Hospital da Luz, Lisbon, Portugal
}

Keywords

Infectious esophagitis · Herpes simplex · Candida

esophagitis

\section{Apresentação enganadora de esofagite infecciosa}

\section{Palavras Chave}

Esofagite infecciosa $\cdot$ Herpes simplex · Esofagite por Candida

A 23-year-old male without relevant medical history presented with a 3-day history of odynophagia, mixed dysphagia, and fever (maximum temperature $38,4^{\circ} \mathrm{C}$ ). Laboratory studies showed mild leukocytosis $(12,000 /$ $\mu \mathrm{L})$. An upper gastrointestinal endoscopy was performed and showed numerous scattered and coalescing, rounded, white plaques in the mid-esophagus (Fig. 1), circumferentially involving the distal esophagus (Fig. 2). Esophageal biopsies were obtained. After the endoscopy, the patient was started on acyclovir and fluconazol pending biopsy results. He tested negative for human immunodeficiency virus and was otherwise non-immunocompro-

\section{KARGER}

E-Mail karger@karger.com www.karger.com/pjg (c) 2019 Sociedade Portuguesa de Gastrenterologia Published by S. Karger AG, Basel

Karger

Open access

This article is licensed under the Creative Commons AttributionNonCommercial-NoDerivatives 4.0 International License (CC BYNC-ND) (http://www.karger.com/Services/OpenAccessLicense). Usage and distribution for commercial purposes as well as any distribution of modified material requires written permission. mised. Histologic examination showed eosinophilic inclusions (Cowdry type A inclusion bodies). Immunohistochemistry confirmed infection by herpes simplex virus. Fluconazol was therefore discontinued after 4 days of therapy, and acyclovir was continued with a total duration of 7 days. Symptoms resolved, allowing for hospital discharge after 5 days.

We present this unusual case of herpes esophagitis in a young immunocompetent patient due to the discordance between the clinical scenario suggesting viral infection and the endoscopy findings more typically found in Candida esophagitis.

Infectious esophagitis is the third leading cause of esophagitis after gastroesophageal reflux disease and eosinophilic esophagitis and it is more common in the immunocompromised host [1]. Candida organisms are the most common cause of esophageal infection [1]. Viral esophagitis is probably the second most common cause and it is typically characterized by odynophagia, retrosternal pain, and fever [2]. Typical endoscopic findings of herpes esophagitis include discrete or coalescent ulcerations of the mid-distal esophagus [1-3]. Nonetheless, it is important to remark that herpes esophagitis can be characterized by white plaques adherent to the esophageal mucosa, typically found in Candida esophagitis. 
Fig. 1. White coalescing plaques in the mid-esophagus.

Fig. 2. Circumferential involvement of the distal esophagus.

\section{1}

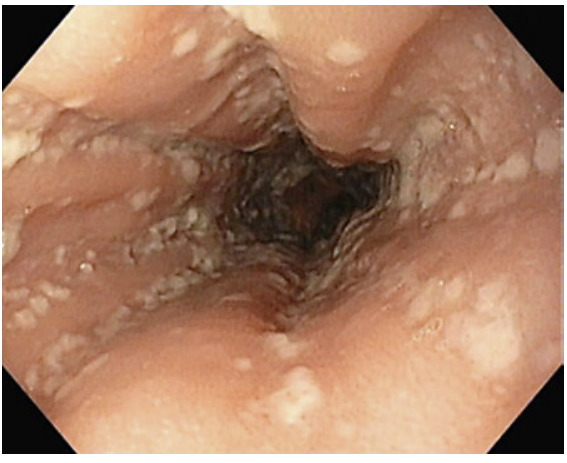

\section{Statement of Ethics}

The authors declare that this case did not require informed consent or review/approval by the appropriate ethics committee.

\section{Disclosure Statement}

The authors declare that they have no conflicts of interest to disclose.
2

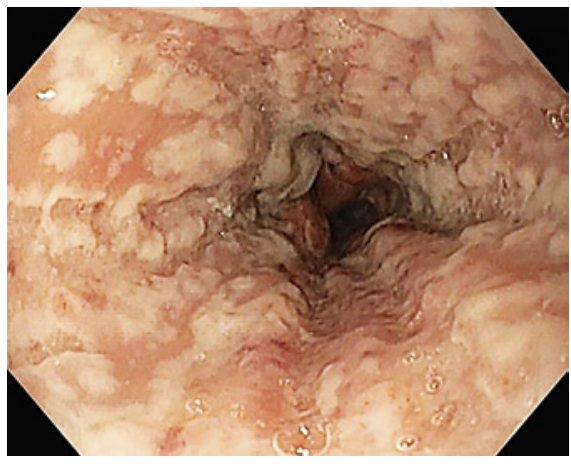

1 Hoversten P, Kamboj AK, Katzka DA. Infections of the esophagus: an update on risk factors, diagnosis, and management. Dis Esophagus. 2018 Dec;31(12):1-9.

2 Wilcox CM. Overview of infectious esophagitis. Gastroenterol Hepatol (N Y). 2013 Aug; 9(8):517-9.

3 Kato S, Yamamoto R, Yoshimitsu S, Shimazaki K, Ogawa S, Itoh K, et al. Herpes simplex esophagitis in the immunocompetent host. Dis Esophagus. 2005;18(5):340-4. 